Balancing Disciplines and Interdisciplines in a New Professional Terrain

\author{
Jean M. O’Brien
}

Professor, Department of History, University of Minnesota

Chair, Department of American Indian Studies, University of Minnesota

aboriginal policy studies Vol. 2, no. 2, 2013, pp.108-114

This article can be found at:

http://ejournals.library.ualberta.ca/index.php/aps/article/view/19008

ISSN: $1923-3299$

Article DOI: http://dx.doi.org/10.5663/aps.v2i2.19008

aboriginal policy studies is an online, peer-reviewed and multidisciplinary journal that publishes original, scholarly, and policy-relevant research on issues relevant to Métis, non-status Indians and urban Aboriginal people in Canada. For more information, please contact us at apsjournal@ualberta.ca or visit our website at www.ualberta.ca/nativestudies/aps/.

UNIVERSITY OF ALBERTA

FACULTY OF NATIVE STUDIES
Aboriginal Affairs and

Affaires autochtones et Développement du Nord Canada 


\section{Balancing Disciplines and Interdisciplines in a New Professional Terrain ${ }^{1}$}

Jean M. O’Brien

Professor, Department of History, University of Minnesota

Chair, Department of American Indian Studies, University of Minnesota

This is a commentary that asks questions and mulls over ideas, rather than offering any concrete answers regarding the institutional and professional challenges we face and what the future might hold, given our efforts to professionalize on our own. How might the advancement of our own independent scholarly agenda, especially as expressed through a proposed new association, proceed in this new professional terrain? We need to ask this question (and many others) fully aware that we are all tied in various ways to traditional disciplines and, sometimes, into the other interdisciplinary formations in which we are invested. What pedagogical, professional, and institutional anxieties precede and proceed from our efforts to professionalize on our own terms? How do we best serve the cause of professional development in Native American and Indigenous Studies?

Much recent scholarship has, quite rightly, focused on the complexity and importance of our intellectual traditions. What I want to do in this commentary is, instead, to take up what I'm going to call our "institutional traditions," a shorthand way of referring to the ways we have-and have not-been accorded space in the academy. I offer these thoughts from the perspective of American Indian (or Native American) Studies more specifically because of my own personal trajectory, but because I also am an advocate of "Indigenous studies" being, more broadly, the best framework in which to do our work.

What might taking the next step in professionalizing Native American and Indigenous Studies mean for the institutional arrangements we work within? How do we best serve our students, given the institutional realities we work within? How do we attend to the tensions between academic and scholarly issues that concern us, and the professional/institutional realities we confront on a daily basis (quite apart from the fact that we are tied in complex ways to multiple communities not typically accorded real priority by higher education as a whole)?

We might do well to begin by asking, what are the institutional arrangements we work within? And, do they work for us? I want to talk about these institutional traditions along two fronts. First, I want to pause to reflect upon how Native American and Indigenous Studies is institutionalized in the academy right now; second, I want to talk a little about how graduate training currently works and how it might work in the future, along with the sorts of concerns that emerge from the structures of graduate training that we do--and might—rely on. To foreground a bit, apart from three Ph.D. programs and a handful of

1 This commentary was originally presented at the Native American and Indigenous Studies Meeting at the University of Georgia in Athens, GA, 10-12 April 2008.

aboriginal policy studies, Vol. 2, no. 2, 2013

ISSN: 1923-3299 
Master's degree programs, training in Native American and Indigenous Studies continues to happen in the disciplines as well as in two interdisciplines (mainly): Ethnic Studies and American Studies, who are (usually) our "closest kin" and (usually) our best allies.

The February 2008 version of the Association for the Study of American Literatures "Guide to Native American Studies Programs in the United States and Canada," edited by Robert M. Nelson, is an incredibly handy tool that permits a quick overview of our institutional terrain. ${ }^{2}$ The ASAIL guide aims "to provide a comprehensive survey of US and Canadian Native American Studies programs being offered as majors, minors, and certifications at the baccalaureate level or above." Let me summarize the findings of this guide, preceded by three important caveats: it does not include information on Tribally Controlled Colleges and Universities; also it is incomplete, because a handful of institutions never responded to inquiries about their programs; and, by its own admission, it may have simply missed programs, even substantial ones.

The guide includes an index by region and by the kinds of programs available at institutions, and tells us the following: there are twenty-two programs across nine states in the eastern US; there are thirty-three programs in twelve states they define as being in the "Northcentral US"; and five more in the "Southcentral US" (e.g., Oklahoma and Texas). So, if you add those together, that's a total of thirty-seven programs in fourteen states in what we might call the "Central US." There are also thirty-seven programs in the twelve states they define as the "Western US" (which includes Hawaii), and there are sixteen programs across seven provinces in Canada. We could add to these numbers seventeen institutions in the US who failed to respond to the survey (which I won't break down by region) and two more in Canada. So, overall, we have 114 Native American, Indigenous Studies, and/or First Nations programs in forty-two US states and eighteen in seven Canadian provinces, signaling a fairly broad institutional presence. ${ }^{3}$

What do these programs do? Forty-six of them offer baccalaureate majors (thirty-four in the US and twelve in Canada). Eighty of them offer baccalaureate minors (seventy-four in the US and six in Canada). Twenty-four of them offer concentrations or certificates (twenty in the US and four in Canada). As for graduate training, there are a total of twentysix programs available: nineteen in the US and seven in Canada. ${ }^{4}$

2 According to Nelson's introductory remarks, this is a revision of the 1993 guide, edited by former ASAIL president Franchot Ballinger, and published by a 1995 ASAIL resolution in hardcopy and electronically. Nelson is currently (as of 2012) in the process of revising this guide again.

3 Eastern US: CT, GA, MA, ME, NH, NY, NC, VA, WV; 22 programs

Northcentral US: IL, IN, IA, KS, KY, MI, MN, NE, ND, OH, SD, WI; 33 programs

Southcentral US: OK, TX; 5 programs

Western US: AK, AZ, CA, CO, HI, ID, MT, NM, OR, UT, WA, WY; 37 programs

Canada: 16 programs.

The guide lists 17 more that declined to provide info-2 in Canada, 15 in US.

$\mathrm{T}=97$ in US; 16 in Canada (or 114 in US and 18 in Canada).

4 Grad programs of any sort $=26.19$ in US; 7 Canada. (1 in AZ; 4 in CA; 2 in NY; 2 in WA; 2 in HI; 1 in $\mathrm{KS} ; 1$ in $\mathrm{MT}$; 2 in $\mathrm{NE} ; 1$ in $\mathrm{OK} ; 1$ in $\mathrm{SD} ; 1$ in $\mathrm{NC} ; 1$ in $\mathrm{WY}$ ) 
The first Ph.D. program in Native American Studies (hereafter NAS) was established at the University of Arizona in 1997, fifteen years after they had established the first MA program. NAS at Arizona has "unique autonomous status" under the graduate college rather than full departmental status, and it also has an undergraduate minor and a J.D./MA program in Law and AIS. Arizona has, by my count from their website in 2008, graduated fourteen Ph.Ds and awarded scads of MAs. In 1998, the University of California, Davis started its Ph.D. program, from which five students have been awarded Ph.Ds (also as of 2008). The third program, established in 1997, is at University of Hawaii-Hilo, where they offer a Ph.D. in Hawaiian and Indigenous Language and Cultural Revitalization (I don't have numbers on graduates from this program).

I should confess at this point that I stumbled on the ASAIL guide through a desperate search of the internet for information to jump-start this commentary, and was previously utterly ignorant of its existence. My discovery of the guide gave me two jolts. First was, This is great! How useful! How come I didn't know about it! How ignorant am I! But, second, I found it listed on the website of my own university, the University of Minnesota, at Morris (one of the branch campuses with a unique program in AIS). It was in the section of the website that points students to graduate programs in NAS-and which did not list the University of Minnesota! This caught my attention. But, of course the website doesn't, because we don't have a formal graduate program in NAS at the University of Minnesota.

Yet, we do lots of graduate training in NAS at Minnesota, like many other placesjust without graduate program status such as a grad "minor," let alone an MA or Ph.D. program. (And, fortunately, we know that the AIS folks in Morris do know we exist and do recommend that their students who are thinking about graduate study give us a look.) In some senses, I think this helps signify the complexity of the institutional traditions that we work within: most of us who work with graduate students do so within the mainstream disciplines or within Ethnic Studies or American Studies programs. I've personally served on dozens of final Ph.D. committees in eleven different departments at Minnesota (mostly in history and American Studies), and have had quite a few advisees of my own (twentyone completed, as of 2012). A recent informal poll of our faculty either in AIS or affiliated with AIS (like I am, even though I'm the AIS chair), yields the following informal results: our nine tenured and tenure-track faculty (whose tenure lines reside in four different departments) collectively advise thirty Ph.D. students in nine different departments across three colleges at the University of Minnesota. If defined as a program, per se, this would be a small yet substantial "graduate program," and we are actually in the habit of mind of thinking of it as such, and I bet lots of the readers of this commentary have a similar story to tell. But graduate training in NAIS, aside from the well-known programs that have achieved programmatic status, operates in the realm of oral culture: you basically have to talk to people to figure out where you might go to get graduate training in a setting that fosters the concerns an interdisciplinary student of NAIS might have. We operate, professionally speaking, in an incredibly haphazard way. Should we be concerned about this? Should we do something about this? 
What implications might further professionalization of our "interdiscipline" have for training graduate students? For envisioning the way we do our work in the future? Most pressingly, if future institutionalization acknowledges and supports the fact of our interdisciplinarity as a mode of inquiry, how will the mainstream disciplines respond?

I raise these questions fully cognizant of a larger concern. We arrive at this moment of organizational synergy at one of the worst times in higher education in recent memory, with the rampant corporatization of the academy. How do we approach our concerns about professionalization in the light of the emergence, and apparently imminent triumph, of the neo-liberal university? I want to frame this section of my commentary with reference to a speaker series we've been running at Minnesota this year at the behest of our nowdeposed dean, who asked the "Ethnic Studies" chairs to collectively ponder the possibility of "efficiencies in institutional arrangements." What he meant, of course, was: "How can you guys make yourselves cheaper to administer?" As the heirs of subversive agendas, our plan is to report back that not only would the sorts of "efficiencies" he envisioned actually cost more in both financial and personal terms, but that the best revision of institutional arrangements would involve a graduate program, the outlines of which we are still mulling over. This speaker series gave me the opportunity, as I struggled to figure out what to say about the commentary I proposed to give here (see footnote 1), to seize upon the observations of a bunch of really smart people and yoke them to my ends.

Chairs and Directors of the Ethnic Studies units named the speaker series "Ethnic Studies in the Neo-Liberal University: Institutionalizing New Critical Paradigms," and came up with a great list of scholars who could help us think about a diversity of existing arrangements. The four we persuaded to come were David Roediger, Lisa Duggan, Michael Omi, and Laureen Chew. ${ }^{5}$

Roediger provided two important insights to our discussions that I think are incredibly important for us to keep in mind. His talk drew on one of his own articles, in which he analyzed "iconic images [such as recruitment brochures] used to represent racial inclusion at what the sociologist Eduardo Bonilla-Silva has tellingly called "historically white colleges and universities. The literal narrative of admission that welcomes students of color to historically white university comes ... [he argues] ... at the high price of effacing the exclusionary past and present of such institutions." ${ }^{\prime 6}$ Riffing off this wonderfully useful formulation of Historically White Colleges and Universities, what would colleges and universities look like if they were conceived of, from the get-go, with general diversity at the center of their purpose? What if colleges and university took authentic stock of the reality of demographic diversity and took diverse populations seriously as their main audience, rather than promoting the liberal idea of open doors and inclusion? What if colleges and universities took seriously their exclusionary practices in order to actualize a truly liberaland liberatory-vision of the world and higher education's place within it? How might Ethnic Studies, in general, play a role in rethinking HWCU? Roediger also talked about the importance of "local arrangements" - that is, all of us are both coming out of particular

5 Laureen Chew was due to present a week after this commentary was presented.

6 In a conversation with Roediger. 
institutional traditions that account for our present-day circumstances, and we all exist in important local contexts regarding our community commitments that are essential to how we configure ourselves.

Omi’s talk, "'It Just Ain't the Sixties No More: The Problems and Promise of Comparative Ethnic Studies," focused on the history of the Ethnic Studies program at Berkeley, and not surprisingly advocated strongly for a Comparative Race and Ethnic Studies approach. His observation is that there is a whole new generation of scholars whose interests, training, and work are more invested in the interdisciplinary than in the disciplinary. The challenge here is that, in the face of interdisciplinarity, departments and mainstream disciplines fear the possibility of their dilution of purpose, and even their potential institutional dissolution, and frequently, especially in the hard social sciences, they erect barriers to protect disciplinary boundaries. Omi cited the derogatory comment of a Berkeley faculty member in the founding moment of the Ethnic Studies program there, who charged Ethnic Studies as being "undisciplined studies." The issue of disciplinary defensiveness was brought home to me during a recent interview for a senior administrative position at Minnesota, where a candidate from a very mainstream social science discipline, when asked to explain her position on interdisciplinarity, fretted over the purity of disciplinary training. Her grounds? Disciplinary "competency" and placement. Certainly placement is a real concern we must take into account. We need to train students who are going to get jobs - that's our very real responsibility. And yet-as a scholarly endeavor that is practically instinctively interdisciplinary-what are we to think and do about this issue? For us, I dare say, "competency" is interdisciplinarity. Still, we have to acknowledge the fact that departments and disciplines have a strong interest in reproducing themselves.

All the speakers quite naturally ended up talking about the relationship between NAIS and what are typically its closest allies (where they exist): Ethnic Studies and American Studies (which has an older, though in its own way also precarious, institutional tradition). Where American Studies exists AND is configured in such a way that is "sympathetic" to NAIS, we can, potentially, forge professional relationships that attend to our needs. Our experience with American Studies at Minnesota, for example, has been generally positive. Not only has American Studies demonstrated their commitment to AIS by asking for and securing faculty searches in AIS over the past two decades, for example, they have also compiled a strong track record of recruiting and supporting Native graduate students. I personally would go further and say that American Studies helped rescue us in the 1980s and early 1990s (another dire time for higher education) when the College of Liberal Arts (where we are housed) was letting us languish, though the other Ethnic Studies units at Minnesota would not offer the same assessment of their history (which they are more likely to dismiss as "colonial.") Also, intellectual tensions exist even within this generally supportive environment. Our students can tell you stories about situations in which they've had to defend their work from the charge that it's "not American Studies," which is, I think our biggest challenge in balancing our interdiscipline with other disciplines and interdisciplines. 
What does institutional autonomy bring? In the academy, this is typically figured as full departmental status. At Minnesota, we'll be marking our fortieth anniversary of attaining this status next year-the first AIS department configured as such. Departmental status typically brings tenure lines, which is nothing to take for granted. When I arrived at Minnesota in 1989, all of the original AIS FTEs had been systematically seized back by the College as people retired or left, and we ran our program on a combination of affiliated faculty and year-to-year contract instructors. What does it mean to not have tenure lines? Without FTEs you are at the mercy of decision-making processes in other institutional locations. Quite simply and very importantly, you can't control your own destiny. Rather than having the power to set your own agenda, you get hires in NAIS when other departments just happen to share your priorities, with no guarantee that these priorities will remain shared in the future.

Programmatically, departmental status brings the possibility of offering undergraduate majors, minors, concentrations, and the like in parity with the mainstream disciplines, and maybe even graduate programs. How might that matter? Without graduate status (and, in a parallel way, faculty hires) we might get students we want admitted to Ph.D. programs and we might just as well not get them. Without our own graduate programs, we can't control admissions decisions and can only influence them through happy local circumstances: does the mainstream department care about diversity? Does it care about NAIS? Does it accommodate the intellectual needs of NAIS, or does it vigorously patrol the boundaries of the discipline? Does it care about creating a climate where students can be both recruited and retained? As a new AIS department chair, I can also now appreciate the following: without graduate program status we have no control over teaching assistant lines and other crucial elements of program staffing for a research university. At Minnesota we have terrific graduate students doing AIS, and AIS has no control over (for lack of a better way to put this) this "labor supply." I know for a fact that we have students who would rather work for us, but whose home departments have their own needs that preclude this.

All of this is by way of asking: What does it mean for graduate training and the development of NAIS as an interdiscipline when mainstream disciplines only accommodate our needs and or interests on the margins? What does it mean for us, for example, when AIS exists only as a "minor" or "concentration" in graduate training in the disciplines? Does this make us marginal, or is it the best we can do given the current constraints of the academy at this moment? Well, I do have to say that if you've got a graduate minor, you at least might show up in someone's list as a place that HAS graduate training!

Sovereignty in the academy is something to take seriously as a valued institutional tradition if we are to control our own destiny, let alone survive the day to day wear and tear of being in the academy-to say nothing about working within and building upon our own intellectual traditions. Among our pressing intellectual concerns are: What does it mean to have NAIS as an interdiscipline? What is our standpoint? How do we talk about our intellectual traditions and how they'll continue to be shaped into the future? What are our theoretical foundations? Our methodologies? What does it take to be a discipline/ interdiscipline? What is our intellectual rationale? There have been vibrant conversations regarding these matters for quite some time. But what about our institutional traditions? 
Now that we are on the verge (we hope) of founding an organization, I think we really should we be thinking collectively about these issues. Other organizations certainly do. So I guess I leave you with one final question: Is there a role for the organization to play in thinking about graduate training and larger concerns about professionalization and, if so, how should we go about this? 